\title{
THE EUROPEAN PILLAR OF SOCIAL RIGHTS: ADDING VALUE TO THE SOCIAL EUROPE?
}

\author{
Diana-Gabriela REIANU, PhD \\ Assistant Professor, Faculty of European Studies \\ Babeş-Bolyai University, Cluj-Napoca, Romania \\ diana.reianu@ubbcluj.ro
}

Adela NISTOR, PhD

Professor, Business School Humber College Institute of Technology and Advanced Learning Toronto, ON, Canada adela.nistor@humber.ca

\begin{abstract}
:
The paper analyses the European Commission's latest major initiative in the social field, the European Pillar of Social Rights, examining the rationale behind this project, the merits and shortcomings of the mentioned proposal. Declared as an initiative that tries to overcome the negative effects of the crisis on the labour markets and social welfare systems, to heal the social wounds of Europe, and to renew convergence within the Euro area, this paper analyses the proposal through the lens of the major challenges that Europe is confronting nowadays, the convergence and divergence trends that we experiment inside the Union. Hence, the paper deals with the following questions: Does this initiative respond to the needs and challenges that Europe is facing today?; Does this initiative envisage policy avenues that encourage social convergence, that are capable of making a decisive impact on poverty, in order to reverse the threat of disintegration that faces the EU today?
\end{abstract}

Keywords: European Pillar, social rights, unemployment, social inequality, social policy

\section{Background and rationale behind: why a European Pillar of Social Rights?}

The EU was formed with the aim to promote peace, democracy, and shared prosperity. Since its creation, the European Union is trying to achieve higher convergence between its Member States, promoting higher economic growth, and reducing imbalances 
between countries and regions. Over the past few years, however, large disparities in economic, labour market and social outcomes emerged across EU countries. The member states are facing huge social challenges, high unemployment rates, and different standards of social security. Furthermore, statistics show that the gap continues to widen inside the Union, that the member states are diverging, are drifting further away from each other in terms of socio-economic performance, converging towards undesirable outcomes, worsening inequalities, widening structural imbalances, and towards higher levels of poverty (Eurostat, 2017).

Being acknowledged that a 'one-size-fits-all' policy solution cannot be implemented at EU level, the policy intervention has to take into account local and regional specificities. Hence, the European Union shall contribute to the improvement of social and economic situation, complementing the actions of the member states, acting in accordance with its core role enshrined in the Treaty on European Union, article 3: "(The Union)... shall work for the sustainable development of Europe based on balanced economic growth and price stability, a highly competitive social market economy, aiming at full employment and social progress, and a high level of protection and improvement of the quality of the environment.(...)." Likewise, article 9 from the Treaty of Functioning of European Union underlines the European Union's role: "the Union shall take into account requirements linked to the promotion of a high level of employment, the guarantee of adequate social protection, the fight against social exclusion, and a high level of education, training and protection of human health" (TFEU, 2012).

In this context, the European Pillar of Social Rights (EPSR), the latest major initiative in the social field of the European Commission, is intended to help guide the social and employment policies, to overcome the negative effects of the crisis on the labour markets and social welfare systems, to heal the social wounds of Europe and to renew convergence within the Euro area. The Pillar is an attempt to defend European social values, to put into motion President Juncker's commitment to secure a "fair and truly panEuropean labour market", to secure "a social triple A rating" for Europe.

The EPSR initiative was first announced by the President of the European Commission in September 2015, in his State of the Union speech, when Juncker declared: "I will want to develop a European pillar of social rights, which takes account of the 
changing realities of Europe's societies and the world of work. And which can serve as a compass for the renewed convergence within the euro area. This European pillar of social rights should complement what we have already jointly achieved when it comes to the protection of workers in the EU. I will expect social partners to play a central role in this process. I believe we do well to start with this initiative within the euro area, while allowing other EU Member States to join in if they want to do so." (EC, 2015)

The preliminary outline of the Pillar was put forward by the European Commission on 8 March 2016 and launched for public consultation. Debates took place from September to mid-October 2016 and the Pillar was open for public consultation until December 2016. On 26 April 2017, the Commission presented the results of the public consultation, together with the final proposal for the European Pillar of Social Rights.

Regarding its content, the Pillar is structured around three main headings and contains core principles for equal opportunities and access to the labour market, for fair working conditions, and for social protection and inclusion. Under these three headings, 20 different policy domains were identified and summarized in key principles that could help the Euro-area countries to achieve upward convergence in the social and employment performance.

Hence, this paper analyzes the proposal through the lens of the major challenges that Europe is confronting nowadays, trying to find answers to the following questions: Does this initiative respond to the needs and challenges that Europe is facing today?; Does this initiative envisage policy avenues that encourage social convergence, that are capable of making a decisive impact on poverty, in order to reverse the threat of disintegration that faces the EU today? In achieving these goals, we will start with an analysis of the current challenges and trends that EU is facing today, so that we can approach the categories of the Pillar and mention the relationship and under what category each challenge fits.

\section{Challenges and threats: current situation in EU (convergence / divergence in EU)}

One of the challenges that EU is facing today is the impact of the crisis on employment. There is a high heterogeneity of employment and social outcomes between Member States, with a significant gap between the highest and lowest performing country. 
Among the Member States, the lowest unemployment rates, in February 2017, were recorded in the Czech Republic (3.4\%), Germany (3.9\%) and Malta (4.1\%), while the highest rates were observed in Greece (23.1\% in December 2016) and Spain (18.0\%) (Eurostat, 2017). Compared to a decade ago, when the ratio of the highest to lowest unemployment rates in the EU was roughly 3 to 1 (between Slovakia and Denmark), recent figures indicate a ratio that exceeds 5 to 1 (between Greece and Germany)" (ILO, 2016).

Table 2.1 Seasonally adjusted unemployment, totals

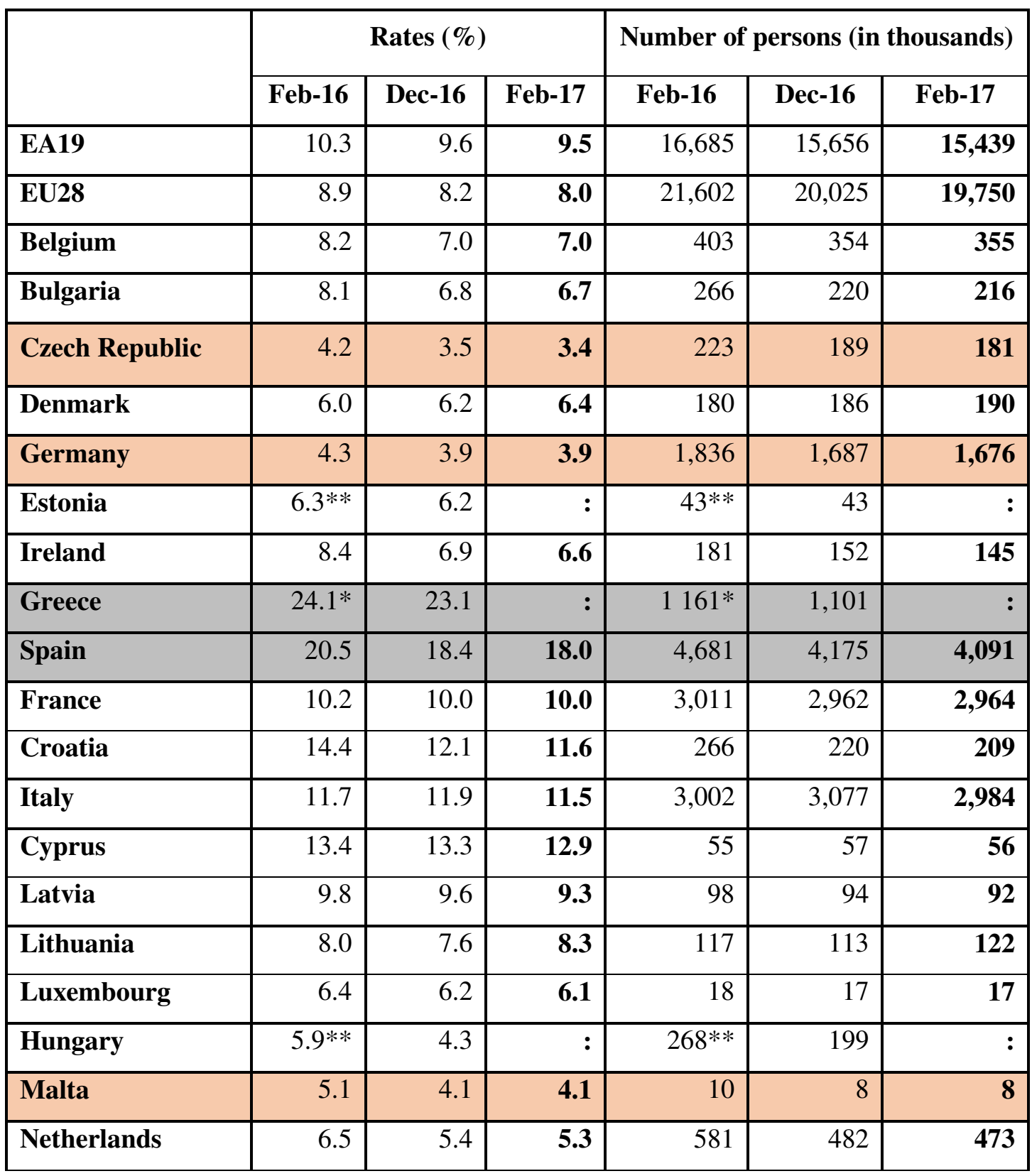




\begin{tabular}{|l|r|r|r|r|r|r|}
\hline Austria & 6.1 & 5.7 & $\mathbf{5 . 7}$ & 273 & 254 & $\mathbf{2 5 5}$ \\
\hline Poland & 6.5 & 5.5 & $\mathbf{5 . 3}$ & 1,125 & 953 & $\mathbf{9 2 1}$ \\
\hline Portugal & 12.2 & 10.2 & $\mathbf{1 0 . 0}$ & 622 & 520 & $\mathbf{5 1 1}$ \\
\hline Romania & 6.3 & 5.5 & $\mathbf{5 . 4}$ & 568 & 493 & $\mathbf{4 8 9}$ \\
\hline Slovenia & 8.2 & 7.9 & $\mathbf{7 . 8}$ & 82 & 80 & $\mathbf{7 9}$ \\
\hline Slovakia & 10.2 & 8.9 & $\mathbf{8 . 6}$ & 282 & 245 & $\mathbf{2 3 8}$ \\
\hline Finland & 9.1 & 8.8 & $\mathbf{8 . 7}$ & 244 & 235 & $\mathbf{2 3 5}$ \\
\hline Sweden & 7.0 & 6.9 & $\mathbf{6 . 8}$ & 368 & 365 & $\mathbf{3 6 6}$ \\
\hline United Kingdom & $5.0^{*}$ & 4.6 & $:$ & $1649 *$ & 1,542 & $:$ \\
\hline
\end{tabular}

: Data not available, $*$ December 2015, ** January 2016

Source: Eurostat, 2017

A significant gap between countries is also registered at the youth unemployment rate, which in February 2017 was $17.3 \%$ in the EU-28 and $19.4 \%$ in the euro area. The lowest rate was recorded in Germany (6.6\%), and the highest one in Greece $(45.2 \%$ in December 2016), Spain (41.5\%) and Italy (35.2\%) (Eurostat, 2017).

What worries in this field are the high rates for long-term unemployment, "in 2015, almost half of all unemployed persons in the EU-28 (48.2\%) had been unemployed for 12 months or more". Again, there are wide gaps between countries; while the situation was bad in Greece (where $73.1 \%$ of all unemployed in 2015 were long-term unemployed people), in northern countries it accounted only for around a quarter or less (ILO, 2016). The consequences of long-term unemployment are very risky, long-term unemployment being dangerous in the way that it leads to low employment opportunities, skills erosion, lower earning potential, and it increases the lifetime risk of poverty and social exclusion. Arulampalam, Gregg and Gregory (2001) underline the connections between unemployment and future wage penalties, emphasizing that unemployment also brings a depreciation of skills during interruptions of employment. They mention that there is evidence that interruptions to employment "inflict a longer-term 'scar' through the increased future incidence of unemployment and lower subsequent earnings in employment". The effects of long-term unemployment will be damaging in the way that they exacerbate lifetime inequality, bringing the individual in the state of risk of poverty and social exclusion (Arulampalam, Gregg, and Gregory, 2001). 
In the Euro-area, the impact of the economic crisis has been profound, persistent divergences in unemployment in the Euro-area being registered: "The unemployment gap between least and most affected countries increased from 8 percentage points during the crisis to 20 percentage points in 2015." (EC, 2016b)

\section{Unemployment rates, 2000-2015 (\%)}

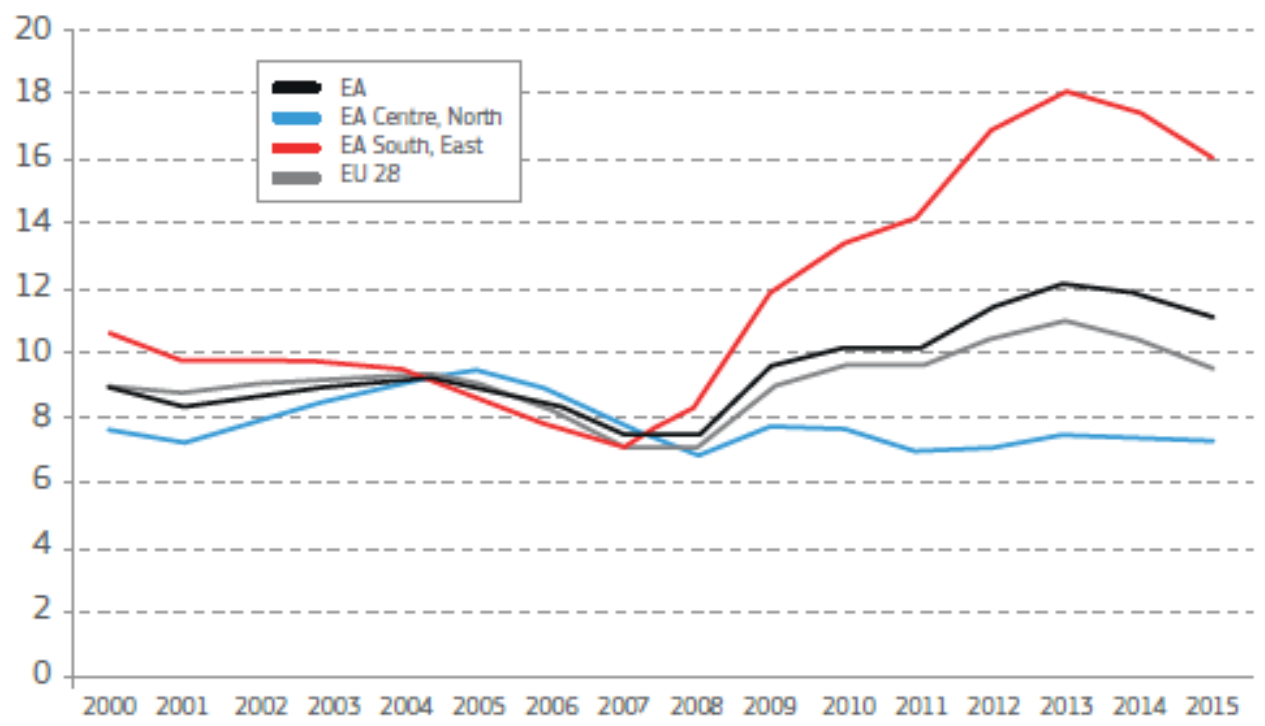

Source: European Commission (2016), Towards a European Pillar of Social Rights. European Pillar of Social Rights: Key economic, employment and social trends

Besides unemployment, structural changes in the labour market have been reflected in an increase of non-standard forms of employment and new labour market characteristics. These changes are mainly the result of the intensification of new technologies and the decline in the employment share of middle-skilled. As a consequence, new types of employment contracts have emerged in the EU recently, contracts that may include temporary employment, temporary agency work and other contractual arrangements involving multiple parties, ambiguous employment relationships, and part-time employment (ILO, 2016). These new forms of employment, these precarious work arrangements and new forms of work with zero-hours contracts, ask for a legal clarity on workers' status and employers' responsibility, mainly because they are used as means of avoiding taxes, social security obligations and decent wages, and prevent workers from exercising legal rights (EESC, 2016). 


\section{Share of temporary contracts and transitions from temporary to permanent}

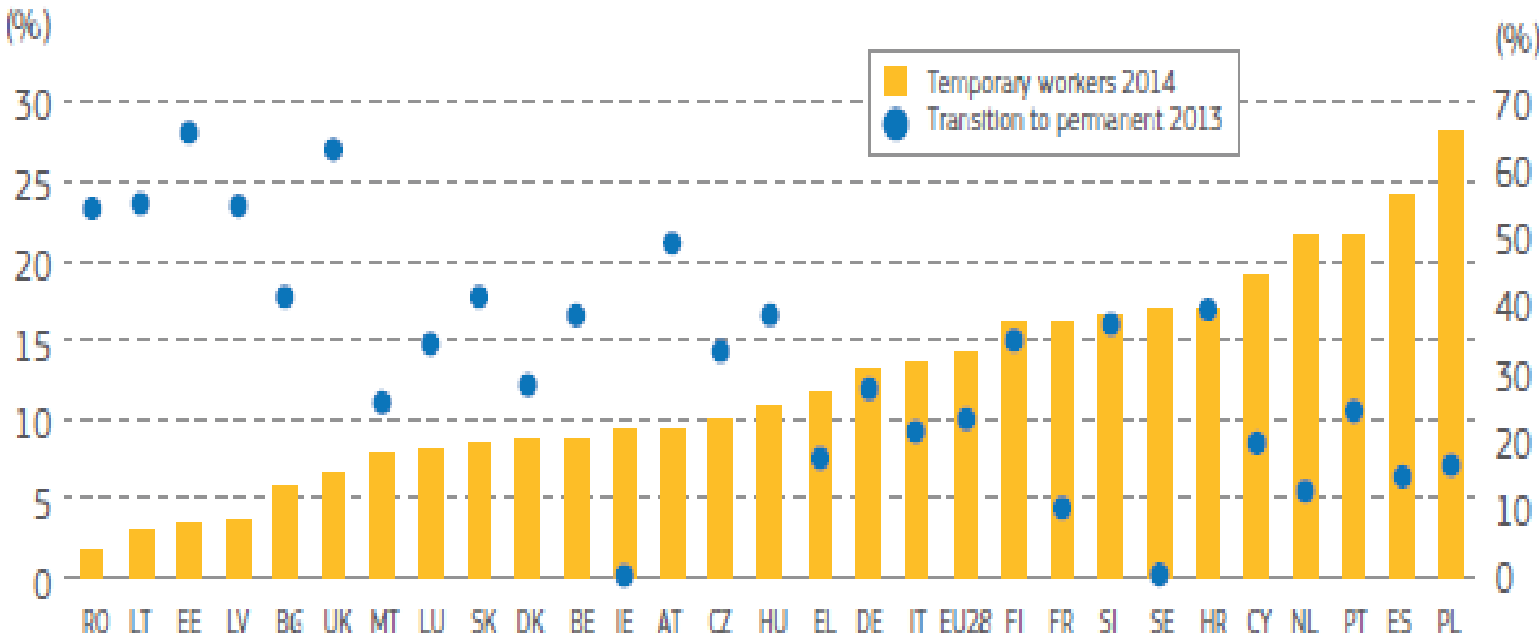

Source: European Commission, Towards a European Pillar of Social Rights. European Pillar of Social Rights: Key economic, employment and social trends

Moreover, a lot of these non-standard forms of employment are involuntary. While part-time work was estimated at nearly $20 \%$ of employment in the EU-28 in 2015, nearly $30 \%$ of these part-time workers were on an involuntary basis. Inside the EU, the trends are very divergent. On one side, "in southern Europe, the share of part-time work that is involuntary is considerable, estimated at $73 \%$ in Greece, over $60 \%$ in Italy and Spain and over 50\% in Portugal in 2015", while "in Eastern Europe, it was also relatively high, at $61 \%$ in Bulgaria and 59\% in Romania". On the other side, "in countries such as Austria, Germany, the Netherlands and the United Kingdom involuntary part-time employment was lower, ranging from $12 \%$ to $17 \%$ in $2015 \%$ (ILO, 2016).

The consequences of these non-standard forms of employment are very diverse. The International Labour Organization shows that "while having a flexible work-force may help firms to address demand fluctuations, and helps workers to cope with their work-life balance, non-standard forms of employment raise several challenges, including limited earning potential, low job security and poor access to on-the-job training" (ILO, 2016).

Labour market characteristics had also changed because of the process of digitization. Technology and digitally powered automation "are producing long-term shifts in occupations, with half of EU jobs at risk of automatisation" (EC, 2016b). The opinion of 
specialized organizations is that "the impact of these developments on the labour market and standards, economy, tax and social security systems and on the living wage must, therefore, be carefully assessed" (EESC, 2016). Because these changes that are occurring in the world of work are many and multi-faceted, we must find ways to prepare workers, to ensure secure transitions between jobs, between statuses and from unemployment to employment, as well as we have to smooth the transition from education to work, for the whole workforce (EESC, 2016). The European Economic and Social Committee had already recommended that the European Commission, the Organization for Economic Cooperation and Development and the International Labour Organization "should work together with the social partners at all appropriate levels and wider civil society organisations, to develop appropriate provisions on decent working conditions and the protection required to take account of new forms of work (such as online work, the gig and sharing economies)". (EESC, 2016)

Among the challenges that Europe is facing, demographic ageing is likely to be of major significance in the next decades. Statistics show that the shape of the EU's age pyramid will suffer transformations because of consistently low birth rates and higher life expectancy. More precisely, the proportion of people of working age in the EU is shrinking, while the number of people retired is increasing. The median age of the EU-28's population was 42.4 years on 1 January 2015 , which means that half of the population was older than 42.4 years, while half was younger. Across the EU Member States the median age ranged between 36.4 years in Ireland, where it registered the lowest median age, and 45.9 years in Germany. The median age in the EU-28 increased between 2001 and 2015 by 4.1 years, rising from 38.3 years to 42.4 years. Romania registered an increase in the median age by 5.5 years during this period, while in countries such as Lithuania, Portugal, Greece and Germany the median age increased by more than 4.0 years (Eurostat, 2016). 


\section{Median age of population, EU-28, 2001-2015}

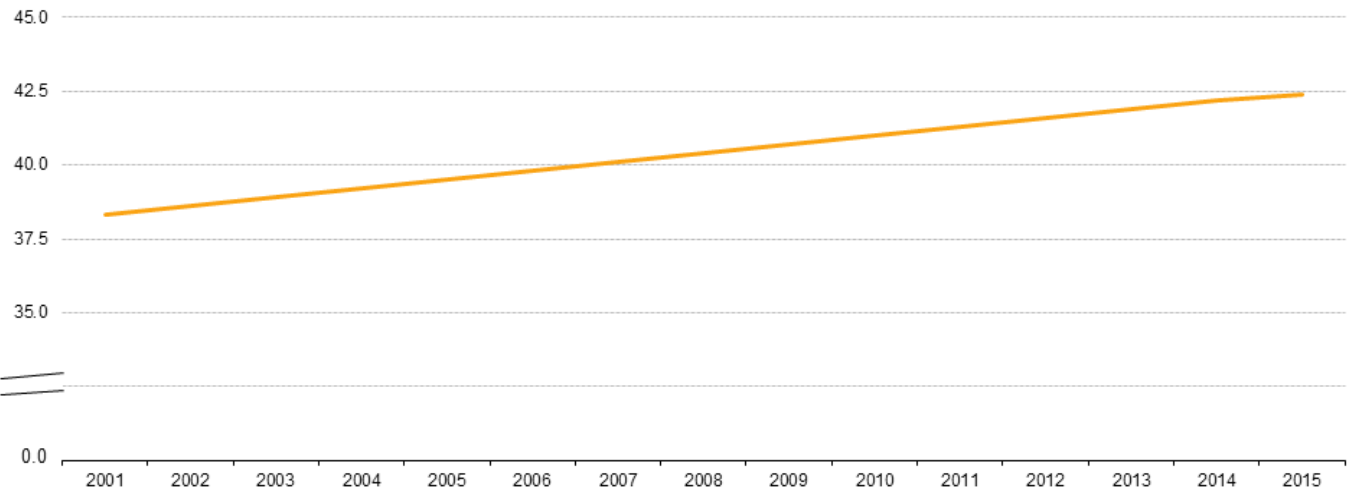

\section{Population pyramids, EU-28, 2015 and 2080 ( $\%$ of the total population)}

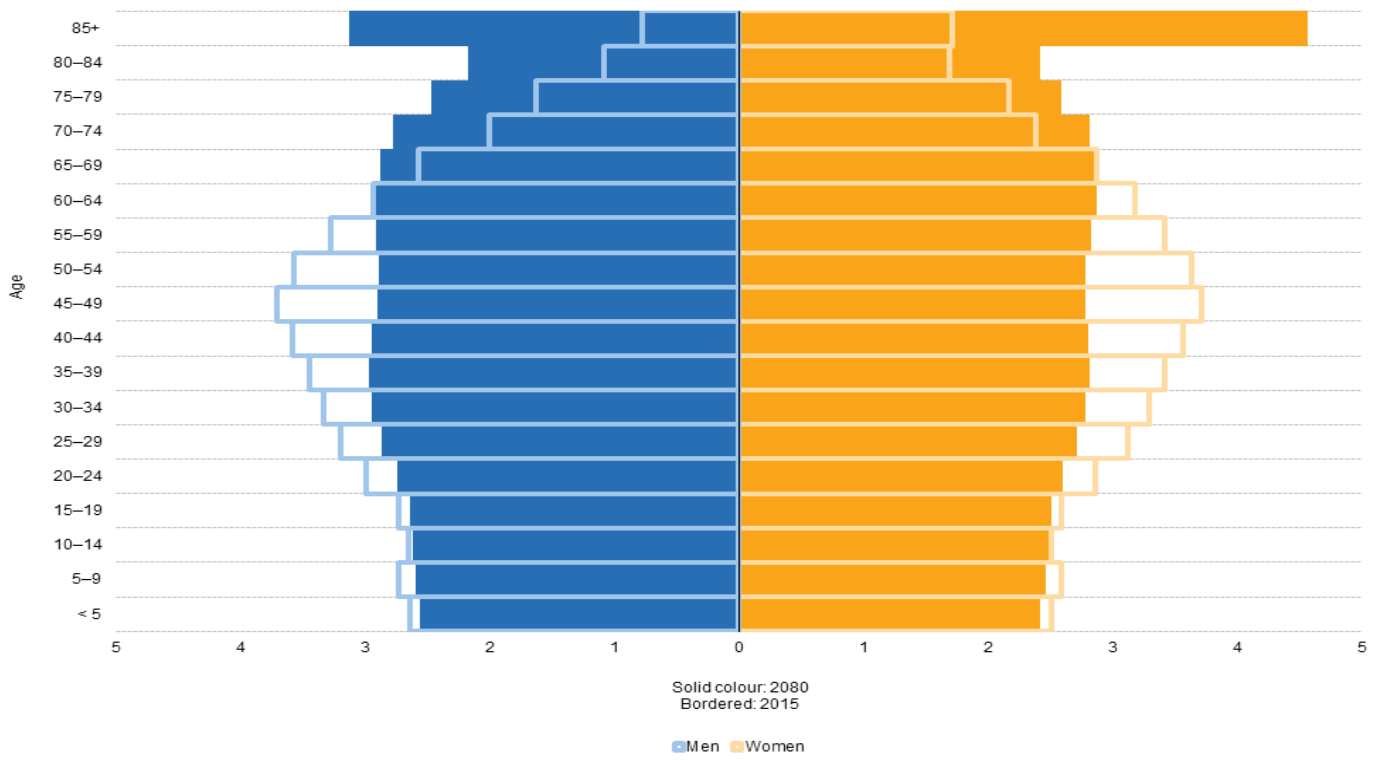

(1) 2015: provsinatiostimate 2080 propections (EUROPOP2013)

Another issue included in the set of challenges faced by the European Union is the dangerous trend of growing social inequality between and within the member states. We 
are now living in a Union with persistent inequalities among the citizens and very high rates of poverty. According to Eurostat data, in 2015, 118.7 million people, or $23.7 \%$ of the population in the EU-28 were at risk of poverty or social exclusion (AROPE). These people were at least in one of the following conditions: at risk of poverty after social transfers (income poverty), severely materially deprived or living in households with very low work intensity.

Table 2.2 People at risk of poverty or social exclusion by age and sex in EU (in thousands)

\begin{tabular}{|c|r|r|r|r|r|r|}
\hline Year & $\mathbf{2 0 1 0}$ & $\mathbf{2 0 1 1}$ & $\mathbf{2 0 1 2}$ & $\mathbf{2 0 1 3}$ & $\mathbf{2 0 1 4}$ & $\mathbf{2 0 1 5}$ \\
\hline Total & 117,678 & 120,667 & 123,614 & 122,703 & 121,897 & 118,820 \\
\hline Men & 54,772 & 56,209 & 57,855 & 57,705 & 57,447 & 56,279 \\
\hline Women & 62,906 & 64,458 & 65,759 & 64,998 & 64,451 & 62,541 \\
\hline
\end{tabular}

Source: Eurostat (2017), Population at risk of poverty or social exclusion by age and sex, (http://ec.europa.eu/data/database), 16 February 2017

The indicators show that Romania, Bulgaria, Greece, Latvia are the countries with the highest rates of at-risk-of-poverty or social exclusion, data confirming considerable variations between EU Member States. In 2015, more than a third of the population was at risk of poverty or social exclusion in Bulgaria (41.3\%), Romania (37.3\%), and Greece $(35.7 \%)$, while at the other end of the scale, the lowest shares of persons being at risk of poverty or social exclusion were recorded in Finland (16.8\%), the Netherlands (16.4\%), Sweden (16.0\%), and the Czech Republic (14.0\%) (Eurostat, 2016).

The International Labour Organization emphasizes this trend of income inequality among the member states, showing that in 2014, "the median incomes of EU countries ranged from around 4,000 purchasing power standard (PPS) in Romania to 28,000 PPS in Luxembourg; this corresponds to a Gini coefficient of equivalized disposable income of around 30.9 (on a scale of 0 to 100 , where 100 denotes maximum inequality) for the EU-28 as a whole; the lowest levels of income inequality were observed in Slovenia (with a Gini coefficient of 25.0), followed by Czech Republic (25.1) and Sweden (25.4); in contrast, the highest levels of inequality were observed in Estonia (35.6), Latvia (35.5) and Bulgaria (35.4)." (ILO, 2016) 
Issue no. $22 / 2017$

\section{Disposable household income, level of inequality, 2005-2014 (Gini coefficient)}

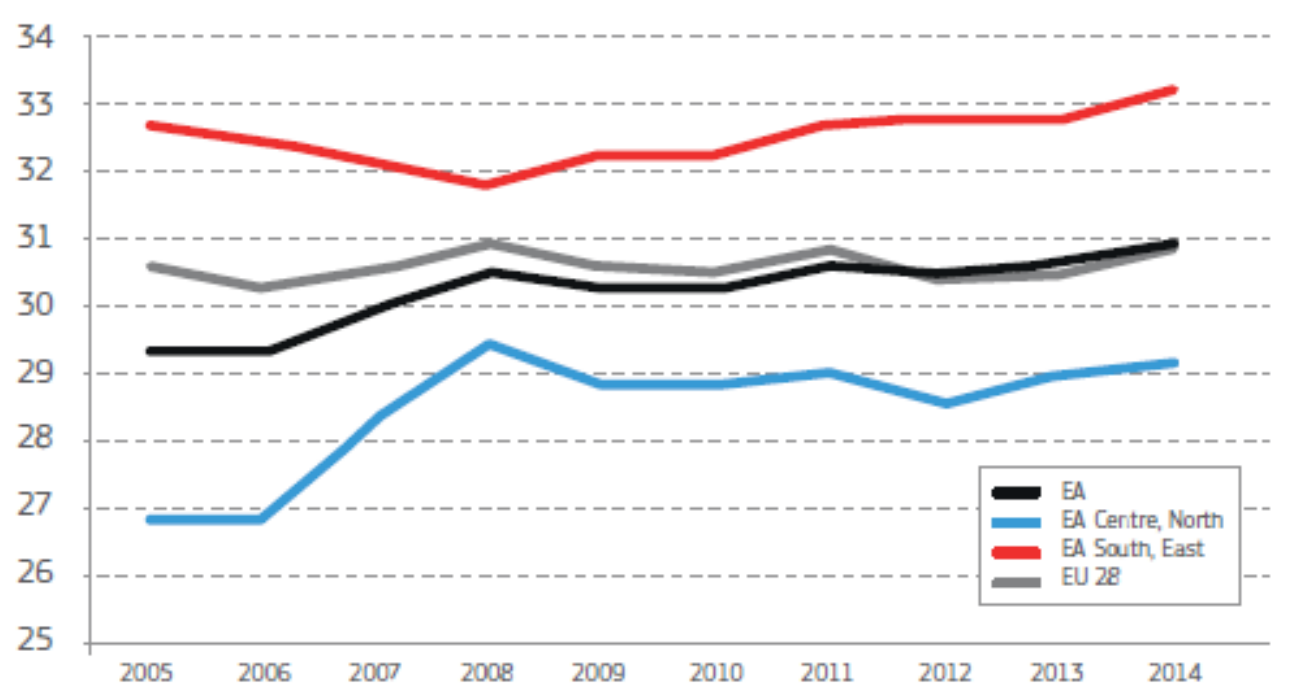

Source: European Commission, Towards a European Pillar of Social Rights. European Pillar of Social Rights: Key economic, employment and social trends

One of the causes of these variations among member states is considered to be the growing polarization between well paid and low paid jobs, which brought an increased in income inequalities among European households (EC, 2016b). Also, we have to look at part-time employment opportunities and women labor force participation on the EU labour market. The literature on part-time employment and women shows a wide range of parttime employment rates in the EU-27 from $2.3 \%$ in Bulgaria to $48.3 \%$ in Netherlands. Women's proportion working part time is different that the men's counterpart and it has also been observed in the Southern European countries such as Italy (28\%) and Spain (23\%) for women and $5.1 \%$ and $4.9 \%$ respectively for men (Cuesta and Carcedo 2014). Part time employment workers are at disadvantage compared to full time workers in terms of access to training (Lyonette et al. 2010). Women in part time jobs face the challenge of reduced the ability to compete in the labor market on an equal foot with men.

So, Rubbery (2015) argues for integrating gender perspective into policy programs with the need for policymakers in the EU to increase women employment and provision of childcare. Current policies to encourage single mother back into the labor force seem to neglect the double burden of work and child care. Another area that could close the gaps between gender inequality is the promotion of women business entrepreneurs and 
supporting the areas that may promote the development of entrepreneurship among women in EU (Grundey and Sarvutyte 2007).

At last, we cannot ignore the economic disparities between the member states and the economic decline at EU level. The GDP, the principal aggregate for measuring economic developments or growth, displays wide disparities across the EU. Eurostat data show that there were five regions where GDP per capita in 2014 was more than double the EU-28 average, the highest level of GDP per capita in the EU being recorded in Inner London-West. Nearly all of the 21 regions in the EU where GDP per capita was less than half the EU-28 average were located in Eastern Europe (Eurostat, 2016). The countries with the lowest income levels within the EU-28 are Bulgaria and Romania, the GDP in these two countries being less than a quarter of the EU average (ILO, 2016). For these reasons, the welfare systems and income support "should guarantee a decent standard of living for all, including employed, elderly and disabled people; good public services must give access to child and elderly care, transport, healthcare and housing." (ETUC, 2016)

\section{Merits and shortcomings - the relevance of the Pillar in today context}

The European Pillar of Social Rights is structured around three main headings or categories (equal opportunities and access to the labour market, fair working conditions, and social protection and inclusion), and includes principles that are grouped according to 20 policy domains, seen by the European Commission as being essential for wellfunctioning and fair labour markets and welfare systems. Hence, after discussing the challenges that Europe is facing today and emphasizing the divergent trends between Member States regarding unemployment, demographic ageing, income inequality and economic growth, we consider of high significance to analyze each category of the Pillar and to establish the relevance of each in today context, so that we may conclude that either the Pillar is responsive to the current needs and is a framework for upward convergence in the euro-zone, or, on the contrary, it lacks substance and includes simple rephrases of existing legal provisions that reformulates social rights in a market-compatible way, like some authors pointed out (Lörcher and Schömann, 2016; Seikel, 2016).

\section{a) Equal opportunities and access to the labour market}


Issue no. $22 / 2017$

One of the big challenges that EU is facing today, argued in the first part of the paper, is the crisis in the labour market. Member States are trying to deal today with the issue of unemployment and with the changes of work patterns which take a very heavy toll on individuals and society by bringing poverty, income inequality, skill erosion, insecurity and a segmentation of the labour market. The link between unemployment and the incidence of poverty and social exclusion was already emphasized by researchers (Corcoran and Hill, 1980). More recently, Cuesta and Carcedo (2014) studied the link between part-time employment and labor market segmentation. They used survey data for the 5 representative EU countries in terms of part-time employment: Denmark, France, Italy, Netherlands and Spain, and among the findings is that there is a labor market segmentation with primary segment full-time jobs and secondary segment the transition between no-employment and part-time jobs. The authors found a positive relationship between the number of household members and the presence of children under age of 12 and non-employment for women in France, Italy and Spain. For the rest of the countries no such correlation has been found. So, from the perspective of part-time employment, the policymakers should promote equal opportunities between these two groups in terms of employment stability in order to achieve equality and reduce labour market segmentation (Cuesta and Carcedo, 2014).

In such conditions, it is welcomed that the European Pillar of Social Rights includes a first category of principles that approach education, training and lifelong learning, gender equality, equal opportunities, and active support to employment. Hence, the Pillar establishes the right to quality and inclusive education, training and life-long learning for everyone, equality of treatment and opportunities between women and men in all areas, the right to equal treatment and opportunities to employment, social protection, education and access to goods and services, regardless of gender, racial or ethnic origin, religion or belief, disability, age or sexual orientation, and the right to assistance and support for the assurance of a good-quality offer of employment or to transfer social protection and training entitlements during professional transitions.

In our opinion, all these principles responds somehow to the current needs of the labour market encouraging a full participation of people in society and a successful transition in the labour market. Problems such as long-term unemployment and youth 
unemployment are seen as solvable through adequate and targeted support offered in a short-time after leaving education or getting unemployed to those who try to enter or reenter work. The support for young people may consist in the form of good-quality offers of employment, continued education, apprenticeship or trainings, while the long-term unemployed have the right to "an in-depth individual assessment at the latest at 18 months of unemployment" (EC, 2017b). The problem of demographic ageing is dealt by encouraging active participation in society and employment, while life-long learning can provide for a smooth adaptation of low skilled young people and working age adults to technological transformations that take place currently on the labour market. The Pillar approaches the issue of gender equality in the labour market and education by supporting equal treatment in all areas, addressing barriers to women's participation and preventing occupational segregation.

One general question arises on how these principles will be put in practice, being unclear from the content how exactly they will be realized, and what the form of action would be. Despite the fact that the principles touch the issues of equal opportunities and access to the labour market, putting on the agenda the current challenges that we are facing, they deal with these challenges in a broadly manner. The Pillar is just defining general actions like ensuring equal treatment, equal opportunities, the right to timely and tailor-made assistance, raising awareness, addressing discrimination, but it does not specify how will be implemented and promoted at national and European level. Who will assure the assistance of unemployed people, how these services will be offered by the national governments, are concerns that arise, taking into consideration that social policy is supposedly a Member States competence and that there are high differences between countries regarding levels of social and employment protection, social investment, and amounts of public resources allocated to social policies and services. The next graph is highlighting such differences, by presenting the expenditure on social protection per inhabitant in each Member State, registered on 2013, using the purchasing power standard (PPS). The highest level of expenditure on social protection per inhabitant in 2013 was registered for Luxembourg (14.7 thousand PPS per inhabitant), followed by Denmark, the Netherlands, Austria, France, Germany, Sweden, Belgium and Finland where social protection was more than 9.0 thousand PPS per inhabitant. By contrast, expenditure in 
Latvia, Bulgaria and Romania was 2.5 thousand PPS per inhabitant or less. These disparities between countries are partly related to different levels of wealth, but may also reflect differences in social protection systems, demographic trends, unemployment rates and other social, institutional and economic factors (Eurostat, 2016).

Expenditure on social protection per inhabitant, 2013 (PPS)

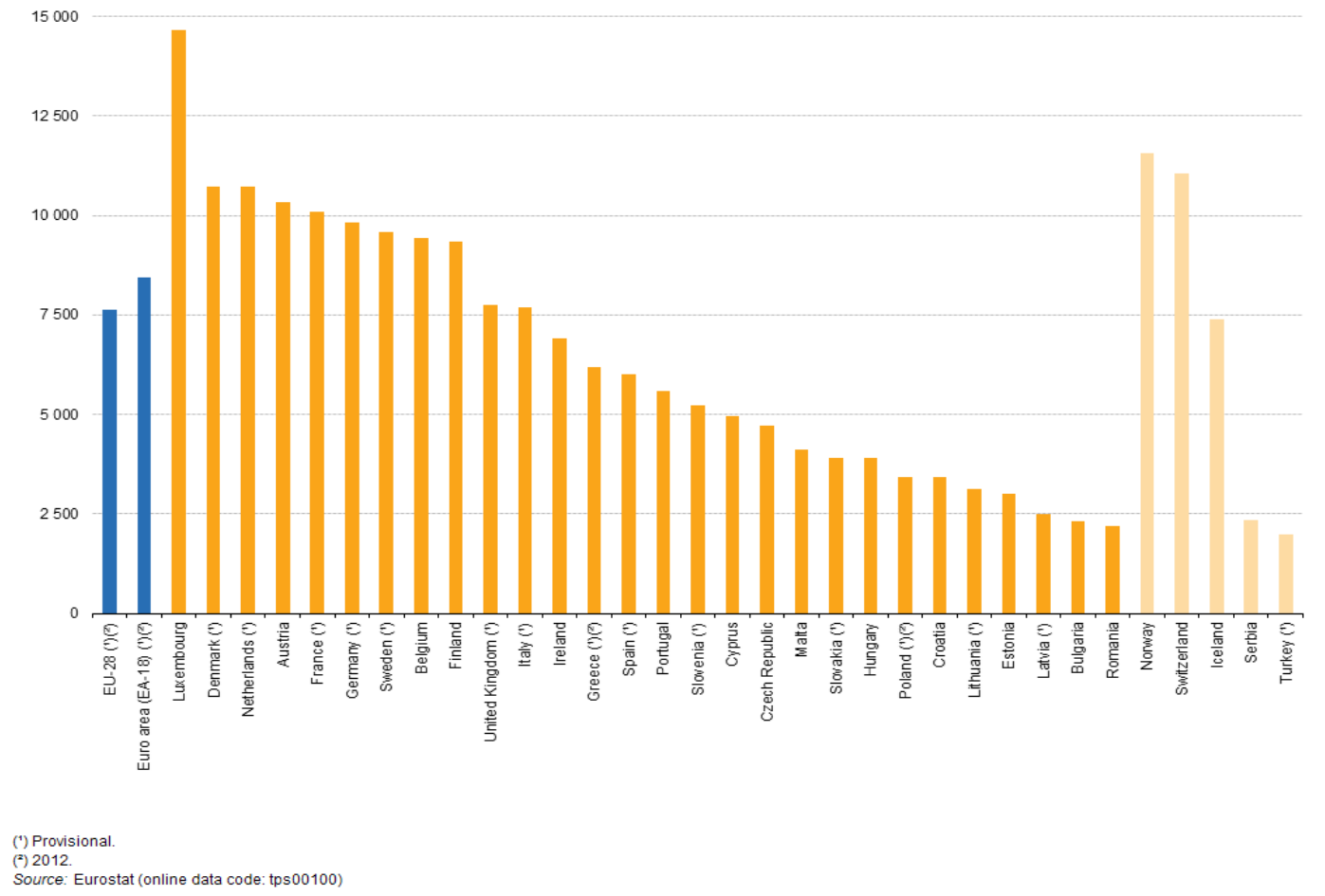

Source: Eurostat, 2016

This lack of clarity over implementation had been previously expressed by the European Anti-Poverty Network in their Position Paper, through questions like: how will the rights be made a reality and who will deliver them; how will the issue of subsidiarity be dealt with; and how will upward convergence be promoted and by what processes (EAPN, 2016). Despite the fact that these observations were made in 2016 with reference to the preliminary outline of the Pillar, the final proposal of the Pillar, published on 26 April 2017, does not provide complete answers.

However, comparing the preliminary outline of the Pillar with the final proposal published lately, we notice some improvements. Particularly, a critical analysis of the preliminary outline of the Pillar made by Lörcher and Schömann stated that the principles 
expressed in the outline needed qualification concerning the standard required, the authors proposing, for instance, a reformulation in terms of right to quality lifelong Learning and vocational training (Lörcher and Schömann, 2016). The final proposal of the European Pillar of Social Rights is addressing those principles in terms of rights, by stating that "everyone has the right to quality and inclusive education, training and life-long learning in order to maintain and acquire skills that enable them to participate fully in society and manage successfully transitions in the labour market" (EC, 2017b).

On the other hand, Lörcher and Schömann (2016) showed concern regarding the active support to employment given to young people, which appears to be identical to the existing legislation on the youth guarantee, but less protective by not specifying the need for working conditions appropriate to the youth age. Unfortunately, the final proposal does not address this omission.

\section{b) Fair working conditions}

The second set of principles configured by the European Pillar of Social Rights refers to fair working conditions, with the aim to offer additional care to new forms of flexible employment and to avoid the unawareness of rights or the unclear information, to avoid abuses, and uneven enforcement of the rules in place. In so far, this category sets rights regarding conditions of employment, wages, health and safety at work, work-life balance and social dialogue. So, it is stated the right of equal treatment regardless of the type and duration of the employment relationship, the encouragement for innovative forms of work, entrepreneurship and self-employment, and the prevention of those employment relationships that lead to precarious working conditions. The workers have the right to be informed in writing about the rights and obligations derived from the employment relationship, at the start of employment, and in case of probation period the duration of it shall be reasonable and any dismissal of a worker should be motivate it and preceded by a reasonable period of notice. Positively, we have to notice over here that information regarding rights and obligations should be given in a written form to every worker at the start of employment. Until now, the Directive 91/533/EEC adopted by the Council of the European Communities on October 14, 1991 stated that the employer had the obligation to inform employees of the conditions applicable to the contract or employment relationship 
Issue no. 22/2017

through a written document, not later than two months after the commencement of employment (Council Directive 99/533/EEC, 1991; Lörcher and Schömann, 2016).

Flexible working arrangements are provided for employers to adapt to changes in the economic context, but only in accordance with legislation and collective agreements, and for parents and people with caring responsibilities, considered to be solutions for assuring a work-life balance and for a reconciliation of family and professional life.

Moreover, the Pillar establishes that employers should ensure an adequate level of protection from risks that may arise at work and should ensure fair wages that provide for a decent standard of living, underlining that "in-work poverty shall be prevented" (EC, 2017b). These remarks, of fairly remunerated employment which enables a decent standard of living and the set of adequate minimum wages want to re-enforce the idea expressed by the Commission's President that a minimum wage should exist in each Member State, so trying to cover the issues of 'grey zones employment' and to tackle the incidence of inwork poverty.

One shortcoming, in our opinion, was the general approach of the preliminary outline of the Pillar regarding the working conditions, which addressed the issue of wages, health and safety conditions without making reference to other forms of employment which can harm the well-being of a worker. The literature in this field includes, for instance, studies on over-qualification, a form of underemployment where people have more skills or experience than required for a job, which is exacerbated by poor job design, especially by a lack of job autonomy (Wu et al. 2015). Wu et al. (2015) used data for 2010 European Working Conditions survey to analyze over-qualification for selected nine European countries representing distinct cultures: Sweden, Denmark, Netherlands, UK, Portugal, Turkey, Estonia, Lithuania, and Latvia. The results suggest that job autonomy may be a good strategy to mitigate the negative effects of over-qualification on the wellbeing of the workers and thus there will be positive beneficial role of job design. The final proposal of the Pillar brings improvements in this field, in the way that provides for the workers' right "to a working environment adapted to their professional needs and which enables them to prolong their participation in the labour market" (EC, 2017b).

In the second category of principles, the Commission also urges for the consultation and the engagement of social partners at EU and national level in designing and 
implementing the economic, employment and social policies and encourages collective agreements. Also, information and consultation in case of collective redundancies, transfer, restructuring or merger of undertakings should be ensured for workers or their representatives.

\section{c) Social protection and inclusion}

One high priority of the European Union is poverty and social exclusion, article 151 of the Treaty on the Functioning of the European Union setting proper social protection and combating of exclusion as objectives of the Union and the Members States. But the responsibility for the social policy lies primarily with national governments, in accordance with the principle of subsidiarity, being considered that it is implemented more effectively at the level of the member states. So, there is a shared competence between the Union and the Member States in regard to the social policy, the role of the Union being only to complement and support the actions of the individual countries.

Despite the struggle of the European Union for achieving a lower risk of poverty and social exclusion, analysis show that the effectiveness of the EU social policy in the field of poverty and social exclusion does not register good results, the level of poverty and social exclusion falling below the EU target, since every $5^{\text {th }}$ EU citizen is at risk of poverty and social exclusion (Peciak and Tusinska, 2015). Moreover, Marerro and Rodriguez (2012) used data on the EU survey of income social inclusion and living conditions for 2005 and estimated the inequality of opportunities for the 23 EU countries. Their findings showed that Nordic, Continental and some Eastern countries are low inequality of opportunities countries, while Mediterranean, Atlantic and some Eastern countries are high inequality of opportunities countries. Among challenges in the agenda of inequality opportunities analysis is the understanding of the main factors (such as institutional, political, or cultural) behind such countries differentials (Marerro and Rodriguez 2012).

In dealing with these issues and challenges, the European Commission integrated in the Pillar of Social Rights a third chapter that contains principles regarding social protection and inclusion. Trying to overcome, in the first place, the problem of the effectiveness of social policy, explained by the lack of integrated benefits and services, the preliminary outline of the Pillar mentioned that the "social protection benefits and services 
shall be integrated to the extent possible", the key to effective support being "a three-fold alignment between social benefits, active support and social services" (EC, 2016a).

In addition to integrated social benefits and services, taking into consideration that demographic ageing, rising longevity and a shrinking working age population are also challenges that bring high costs of treatments and a high pressure on the financial sustainability of health and pension systems, the final proposal of the Pillar does provide for healthcare, pensions, unemployment benefits, minimum income, disability, long-term care, childcare, housing, and access to essential services. Even so, the financial sustainability of health systems and the universal access to high quality can increase social cohesion, but still remains a challenge. Pensions, on the other side, shall ensure an adequate income at retirement age for all persons, but still there is a high gender pension gap in most countries, with women's lower earnings leading lo lower pension contributions and lower entitlements. For this reason, the preliminary outline of the Pillar proposed that the "pension systems shall strive to safeguard the sustainability and future adequacy of pensions by ensuring a broad consultation base, linking the statutory retirement age to life expectancy and by closing the gap between the effective retirement and statutory retirement age by avoiding early exit from the labour force" (EC, 2016a), but this would also lead to later retirement, or, as Lörcher and Schömann (2016) emphasizes, to an assault on pre-retirement policies.

The minimum income benefits shall be ensured for all persons that lack sufficient resources for a decent standard of living, in terms of the Pillar, but with an emphasis on the link between active support and social services for those of working age, in order to encourage labour market integration/re-integration. Lörcher and Schömann (2016) criticized the preliminary outline of the Pillar, considering that the condition of participation in active support is a very important restriction of the right, so it should not be retained in the content of the Pillar. Therefore, the final proposal enshrined the right to adequate minimum income for everyone lacking sufficient resources, with the indication that for those who can work, the benefits should be combined with incentives to (re)integrate into the labour market.

We highly agree that the Pillar provides for inclusion of people with disabilities with the specific mention that the work environment should be adapted to their needs. 
Also, the Pillar enshrines the right of the children to be protected from poverty and the right of everyone in old age to resources that ensure living in dignity, taking into consideration that children and old-age persons are facing a higher risk of poverty and social exclusion. Also, the access to social housing or housing assistance and the access to essential services are new principles enshrined in the Pillar on the basis that the lack of adequate housing forms a barrier for labour mobility, for an independent living and a fulfillment of life plans, while the lack of essential services (such as sanitation, energy, transport, financial services) does not assure the full social inclusion and equal opportunities for all people.

\section{Conclusions}

As a conclusion, the Commission's initiative under the form of the European Pillar of Social Rights, followed by a lot of reactions and concerns regarding its content, its legal nature, and its implementation, raised our own interest and desire to search for answers to disputed questions.

We consider on one side the authors who criticize the preliminary initiative, stating that either the Pillar does not include social rights as expected, as the name of it suggests, and that it includes only guidelines and principles, some of them being more concrete specifications, simple repetitions or rephrases of existing legal provisions (Seikel, 2016), or that the Pillar doesn't have a clear legal nature, most probably being not intended to be enshrined in the EU primary law, so not having the power to enforce rights in court (Poulou, 2016). As a result, the European Commission declares that the principles and rights enshrined in the Pillar are not directly enforceable, requiring a translation of them into appropriate action or legislation, the Pillar being presented in the form of a Recommendation, its implementation being primarily the responsibility of national governments, of public authorities and of social partners (EC, 2017a).

Also, there are concerns that refer to the fact that the principles proposed in the outline of the Pillar are suggested to serve firstly to traditional aims of economic policy, such as fiscal sustainability and economic competitiveness, than to social objectives such as equity, accessibility or quality of social services which should be the foster elements of the EU's social dimension, thus the Pillar "treats social policy as subordinate to economic 
Issue no. 22/2017

policies" (Poulou, 2016). Similar statements appear in texts delivered by specialized organizations, experts and committees who affirm that the Pillar lacks ambition and clarity over implementation, gives priority to macroeconomic objectives instead of poverty and social exclusion, and fails to distinguish between policy means and social ends (EAPN, 2016; EESC, 2016; ETUC, 2016).

Another main issue of disapproval is that the Pillar is addressed only to the Eurozone, so it needs further clarification on why will it be applied only to the Member States of the Euro-area and other member states who want to join it and how this will be done. Related to this, there are many questions not answered yet. Why the common currency is the criterion used for deciding the focus of the Pillar? Is this an economic rationale? Why does the Pillar leave the initiative open to other member states on a voluntary basis, in comparison to other legal documents which are binding on the European Union as a whole? Could this lead to further increased intra-EU migration towards countries with better social welfare provisions? Will this also increased divergence across EU? Will it foster a two-speed Europe? How the risks of becoming a two-speed social Europe will be avoided? We do believe that such an initiative envisaged to create a more Social Europe but applied only to countries in the Euro-area will actually bring disparity, will lead to higher inequalities and social dumping, will end up in creating a two-speed European Union. We proved that differences and divergences are present nowadays among countries, and we emphasized this through studies and statistics in the first part of the paper, so we ask ourselves what good can deeper differences bring.

On the other side, our analysis is highlighting the positive aspects of the Pillar. Such as, the Pillar is perceived as an opportunity to "underline the qualitative differences between economic and social policy and to disprove the conviction prevailing in post-crisis economic governance that the collapse of the distinction between fiscal goals and social policy is irreparable" (Poulou, 2016). Also, the Pillar contains progressive approaches, ensuring the equal use of leave arrangements by parents, addressing the gender pension gap, and emphasizing the growing importance of long-term care as well as of 'essential services' (Seikel, 2016). In our opinion, the principles of the Pillar touch the issues of equal opportunities and access to the labour market, the need for social protection and 
social inclusion, putting on the agenda the current challenges that we are facing, but it deals with some of these issues too generally, too broadly.

Hence, we consider that in order to reverse the threat of disintegration that EU is facing today we need more concrete actions and measures, a higher priority given to social protection, more security in the labour market, a higher importance given to social investment and social innovation, and a universal application of the rights, principles, and actions to the EU as a whole.

\section{References}

1. ARULAMPALAM, W., GREGG, P., GREGORY, M. (2001), "Unemployment scaring", The Economic Journal, Vol 111, Issue 475(577-584)

2. CONSOLIDATED VERSION OF THE TREATY ON THE FUNCTIONING OF THE EUROPEAN UNION (TFEU) (2012), Official Journal of the European Union, C326/53

3. CORCORAN, M., HILL, M.S. (1980), "Unemployment and poverty”, Social Service Review, Vol. 54, No. 3(407-413)

4. Council Directive 99/533/EEC (1991) on an employer's obligation to inform employees of the conditions applicable to the contract or employment relationship

5. CUESTA, M., CARCEDO, J. (2014), “Women's part time jobs: flexirisky employment in five European countries", International Labor Review 153(2)

6. EUROPEAN ANTI-POVERTY NETWORK (EAPN) (2016), Last Chance for Social Europe? EAPN Position Paper on the European Pillar of Social Rights

7. EUROPEAN COMMISSION (EC) (2015), State of the Union 2015: Time for Honesty, Unity and Solidarity, Speech, Strasbourg, (http://europa.eu/rapid/pressrelease_SPEECH-15-5614_en.htm]

8. EUROPEAN COMMISSION (2016a), Communication from the Commission to the European Parliament, the Council, the European Economic and Social Committee and the Committee of the Regions, Annex: First preliminary outline of a European Pillar of Social Rights, COM 127 final, Strasbourg

9. EUROPEAN COMMISSION (2016b), Towards a European Pillar of Social Rights. European Pillar of Social Rights: Key economic, employment and social trends 
10. EUROPEAN COMMISSION (2017a), Communication on Establishing a European Pillar of Social Rights, COM 250 final, Brussels

11. EUROPEAN COMMISSION (2017b), Recommendation on the European Pillar of Social Rights, C 2600 final, Brussels

12. EUROPEAN ECONOMIC AND SOCIAL COMMITTEE (EESC) (2016), Opinion: The European Pillar of Social Rights, SOC/542

13. EUROPEAN TRADE UNION CONFEDERATION (ETUC) (2016), Position on the European Pillar of Social Rights, European Pillar of Social Rights - Working for a Better Deal for All Workers, (https://www.etuc.org/documents/european-pillar-socialrights-\%E2\%80\%93-working-better-deal-all-workers\#.WNyzsNKLTcv)

14. EUROSTAT (2017), (http://ec.europa.eu/eurostat/statisticsexplained/index.php/Unemployment_statistics\#Recent_developments_in_unemploym ent_at_a_European_and_Member_State_level)

15. GRUNDEY, D., SARVUTYTE, M. (2007), "Women entrepreneurship in the European labor market: time to go online". Transformations in Business and Economics 6(2)

16. INTERNATIONAL LABOUR ORGANIZATION (ILO) (2016), Building a social pillar for European convergence, Geneva: ILO

17. LÖRCHER, K., SCHÖMANN, I. (2016), The European pillar of social rights: critical legal analysis and proposals, Brussels: European Trade Union Institute

18. LYONETTE, C. BALDAUF, B., BEHLE, H. (2010), "Quality part-time work: A review of the evidence". Institute for Employment Research, University of Warwick. London, Government Equality Office

19. MARERRO, G., RODRIGUEZ, J. (2012), "Inequality of opportunity in Europe". Review of Income and Wealth 58(4)

20. PECIAK, R TUSINSKA, M. (2015), “The fight against poverty in European Unionexpectations versus reality", Journal of International Studies 8(2)

21. POULOU, A. (2016), Towards a European Pillar of Social Rights: An Opportunity Not To Be Squandered, (https://www.socialeurope.eu/2016/05/45300/) 
22. RUBERY, J. (2005), "Reflections on gender mainstreaming: an example of feminist economics in action", Feminist Economics 11(3)

23. SEIKEL, D. (2016), The European Pillar of Social Rights - No 'Social Triple A' For Europe, on Social Europe, (https://www.socialeurope.eu/2016/03/european-pillarsocial-rights-no-social-triple-europe/)

24. WU, C., LUKSYTE, A., PARKER, S. (2015), "Overqualification and subjective wellbeing at work: the moderating role of job autonomy and culture", Social Indicators Research 121(3) 